Research Article

\title{
The Implications of Area Morphology and Particulate Matters' Distributions on the Kwa Iboe River Basin Restoration, Southeastern Nigeria
}

\author{
Ikpong Sunday Umo*, Angela Iweka Enwereuzor \\ Department of Geography and Environmental Studies, Alvan Ikoku Federal College of Education, Owerri, Nigeria \\ Email address: \\ umohikpong@yahoo.com (I. S. Umo) \\ ${ }^{*}$ Corresponding author
}

\section{To cite this article:}

Ikpong Sunday Umo, Angela Iweka Enwereuzor. The Implications of Area Morphology and Particulate Matters' Distributions on the Kwa Iboe River Basin Restoration, Southeastern Nigeria. Journal of Water Resources and Ocean Science. Vol. 10, No. 3, 2021, pp. 53-60.

doi: $10.11648 /$ j.wros.20211003.13

Received: May 24, 2021; Accepted: June 7, 2021; Published: June 22, 2021

\begin{abstract}
The upsurge pressure from natural and anthropogenic agents at the Kwa Iboe River ecology necessitates the exploration of the association of area morphology and particulate matters' distributions with a view to developing sound policy for the protection and sustainability of its heritage. This study uses direct field survey and laboratory techniques. The area morphology of the Kwa Iboe River Basin (KIRB) was delineated using Shuttle Radar Topography Mission on a 30 meter resolution for the determination its size. Using stratified and systematic sampling methods, eight sampled sub-units comprising one first-order stream, six fourth order tributaries, and the estuary were selected. A set of core bedload samples were collected along each transect during the months of November (2017), February (2018), and July (2018); homogenized, treated, and analyzed to ensure standard compliance to the National Research Laboratory Umudike. Data generated were analyzed descriptively and inferentially. The results showed the dominant of mean sand fraction across seasons and sub-basins. A linear regression model of the influence of area morphology on the distributions of particulate matters generated a high coefficient of 0.954 that explained 90.9 percent of the total variance. The analysis of variance test of the influence at 0.05 confidence level showed that variations in area morphology have no significant influence on particulate matters' (sand, silt, clay, organic matter, and organic carbon) distributions in KIRB. The study recommended (i) strict implementation of the basin management plans to avert natural and anthropogenic activities that accelerate siltation and drying of Kwa Iboe River tributaries, losses of terrestrial habitats, and pollution of surface water. (ii) Enforcement of existing laws to facilitate stringent control of human exploitative excesses with obvious negative implications on the KIRB ecology in this post-modern age.
\end{abstract}

Keywords: Area Morphology, Kwa Iboe Ecology, Particulate Matters, Eco-geomorphologic Units, River Restoration

\section{Introduction}

\subsection{Background}

The prevalence of environmental and geo-physical hazards across distinct eco-geomorphologic units (geographic spaces) and time during this post-modern age suggests the need to protect and conserve river and marine ecologies from the devastating consequences of biodiversity loss and the potential extinction of some exotic, yet endangered fauna and flora species. The rapid despoliation of tropical rainforest and river systems for diverse benefits and uses such as agriculture, mining, urbanization, industries, and infrastructure as triggered by poverty, politics, climate change, population explosion, militia, and allied activities are among the dominant variables that exerts pressure and negative feedback mechanisms on freshwater (river) ecosystem and particulate matters' accumulations at the riverbeds within a basin scale.

The quantitative analyses of area morphology of distinct rivers within the humid Tropics have been applied in geomorphic researches such as [1-3], but with much variances in contexts, contents, methods and ideologies. For instance, 
the applications of remote sensing and allied technologies in the derivations and quantitative assessments of morphological attributes had attracted attention in India [4]; Oba River [5] and in Ikpa River [2, 3].

The attempts to elucidate the effect of area morphology on particulate matters' distributions and the corresponding implication on river ecosystem protection and restoration within the Southeastern Nigeria are rather eclipsed in this $21^{\text {st }}$ century. If such study is conducted at a basin scale, the geologic and geographic structures that control the watershed as well as the landform evolution and denudational history can be easily comprehend and elucidate.

Empirical evidences indicate that physical geographers and earth scientists have devoted most of their research efforts, time, and other resources to facilitate the understanding of the dynamics of river processes and landforms from the inter-disciplinary perspective in the $21^{\text {st }}$ century [6]. In the context of River basins, topography, vegetation, climate, geology, and human activities are among the focal factors that facilitate weathering, erosion, transportation, and deposition $[7,8]$. Understanding of space - time dynamics among the surficial phenomena is at the core of geomorphologic research [9], especially the influence of area morphology on particulate matters' distributions at a river basin scale.

In Barlad basin of Romania, Zavoianu [10] assessed the relationship of suspended sediment load and drainage morphometric indicators using indirect method. The result indicated that suspended particle load was influenced by the sums of the number and length of stream segments while the relationship symbolized a good representation of the diversity of geographic factors (e.g. erosional processes) in the basin.

In Northern Nigeria, [11] studied the rate of sedimentation of Kano River Irrigation. Five canals were systematically sampled, and the base lines taken with reference to the transect using simple random sampling. The result showed $76 \%$ of sand, $12 \%$ of silt, and $12 \%$ of clay. In depth field survey revealed a reduction in canals discharge by $47 \%$ due to increased silting from human activities.

The strategic location, immensity, historical, and the socio-economic values attached to Kwa Iboe River (KIR) suggest the need to protect its ecology from siltation and despoliation emanating from anthropogenic and geophysical agents that are operational in the scale. Hence, the cardinal issues agitating the mind of the researchers are: (i) what are the dominant characteristics of particulate matters across the major tributaries of KIRB? (ii) Do variations in basin area morphologies have significant influence on the distributions of particulate matters (sand, silt, clay, organic carbon, and organic matter) in KIRB? The identified issues are chronological addressed in this study.

\subsection{Aim and Objectives of the Study}

The paucity of knowledge regarding basin area morphology and its influence on spatio-temporal distributions of particulate matters in the Kwa Iboe River Basin, Southeastern Nigeria is the aim of this article. To accomplish the aim, the following two specific objectives were investigated.
1. To examine the spatio-temporal variations in the distribution of particulate matters in the Kwa Iboe River Basin of Southeastern Nigeria.

2. To evaluate the effect of variations in basin area morphologies on particulate matters' distributions in the Kwa Iboe River Basin of Southeastern Nigeria.

\subsection{Research Hypothesis}

The study is guided by a null hypothesis that states thus: "Variations in basin area morphologies have no significant effect on the particulate matters' (sand, silt, clay, organic matter, and organic carbon) distributions in the Kwa Iboe River".

\subsection{Description of the Study Area}

The Kwa Iboe River (KIR) is located approximately between Latitude $4^{\circ} 20^{\prime}$ and $5^{\circ} 40^{\prime}$ North of the Equator and Longitude $7^{\circ} 10^{\prime}$ and $8^{\circ} 25^{\prime}$ East of the Greenwich Meridian (Figure 1). The River takes its source from Okwuta community in Umuohia North, Abia State where it flow in a south direction as a first-order stream, joined by other tributaries to drained many Local Councils in Abia and Akwa Ibom States and empties into the Atlantic Ocean in two communities (Itak Abasi on the East and Inua Eyet Abasi on the West) at Ibeno [8].

There are two dominant geologic formations that underlain KIR area. These geologic formations are the coastal plains sands, and the beach complex and alluvial deposits (Figure 1). However, traces of geologic formations notably the sand-gravel facies (Ameki formation) and the shale-limestone facies (Imo shale) that are older and occupy very small portion along the divides of the Imo, Itu, and Kwa Iboe Rivers [8, 12]. The coastal plains sands cover over 60 percent of the entire basin area. The unique and dominance geologic attributes in the coastal plain sand is the combined facies of sand and gravel which is the older Benin formation and is partly dated to the Oligocene-Pleistocene period $[8,13]$.

The beach complex and recent alluvium are found in the Creeks, shores, and estuarine regions of the River Basin are made of late tertiary deposits. It is made up of clay minerals and mudstones as found around Upper part of Ubium River and Nsit clan, while quaternary alluvium are prevalence in the middle and Lower parts of the estuarine notably Stubbs and Douglas Creeks, and the Estuary (Figure 1).

The vegetation is dominated by humid tropical rainforest at the upper and middle sub-basins but persistently altered by diverse human occupation, leaving behind some isolated primary forests along the wetland areas. The mangrove vegetation are found along the woodland and meander segment in Ibeno bordering the Atlantic Ocean with Creeks, beach-ridges, ebb flow, sandy patches $[8,20]$. The climate is humid tropical (Am climate) based on Koppen classification scheme with double maxima of rainfall and temperature amounts.

\section{Materials and Methods}

Data for this study were generated from primary and 
secondary sources. The primary data were generated from direct field surveys and laboratory analyses of periodic concentrations of particulate matters in bedload sediment and mapping of area morphology. The secondary data were obtained from topographic maps, satellite imageries (through the State Survey, Federal Survey, and Planning Departments), and other published documents.

The Kwa Iboe River Basin was divided into eight sub-units comprising one (1) first-order tributary where the basin originated from, six (6) fourth order Rivers (Anya River, Azuihe River, Awa River, Eteku River, Ubium River, and Stubbs River), and estuary where the River enters the Atlantic
Ocean (see Figure 1). In each of the sampling points, grab samples were collected along transects in an undisturbed manner and their coordinates recorded using Global Positioning System (GPS).

Area morphologic analysis of Kwa Iboe River was carried out using Shuttle Radar Topography Mission (SRTM) with $30 \mathrm{~m}$ resolution. The image (Raster) was used for watershed delineation and in derivation of the morphology area was complemented with the topographic maps (Afikpo 313 SW; Ikot Ekpene 322 NE; 322 SW) each produced on a scale of 1:50,000 by Federal Survey, Lagos to avert the limitation of dense vegetation that eclipsed the river channel in the satellite imagery (Raster).

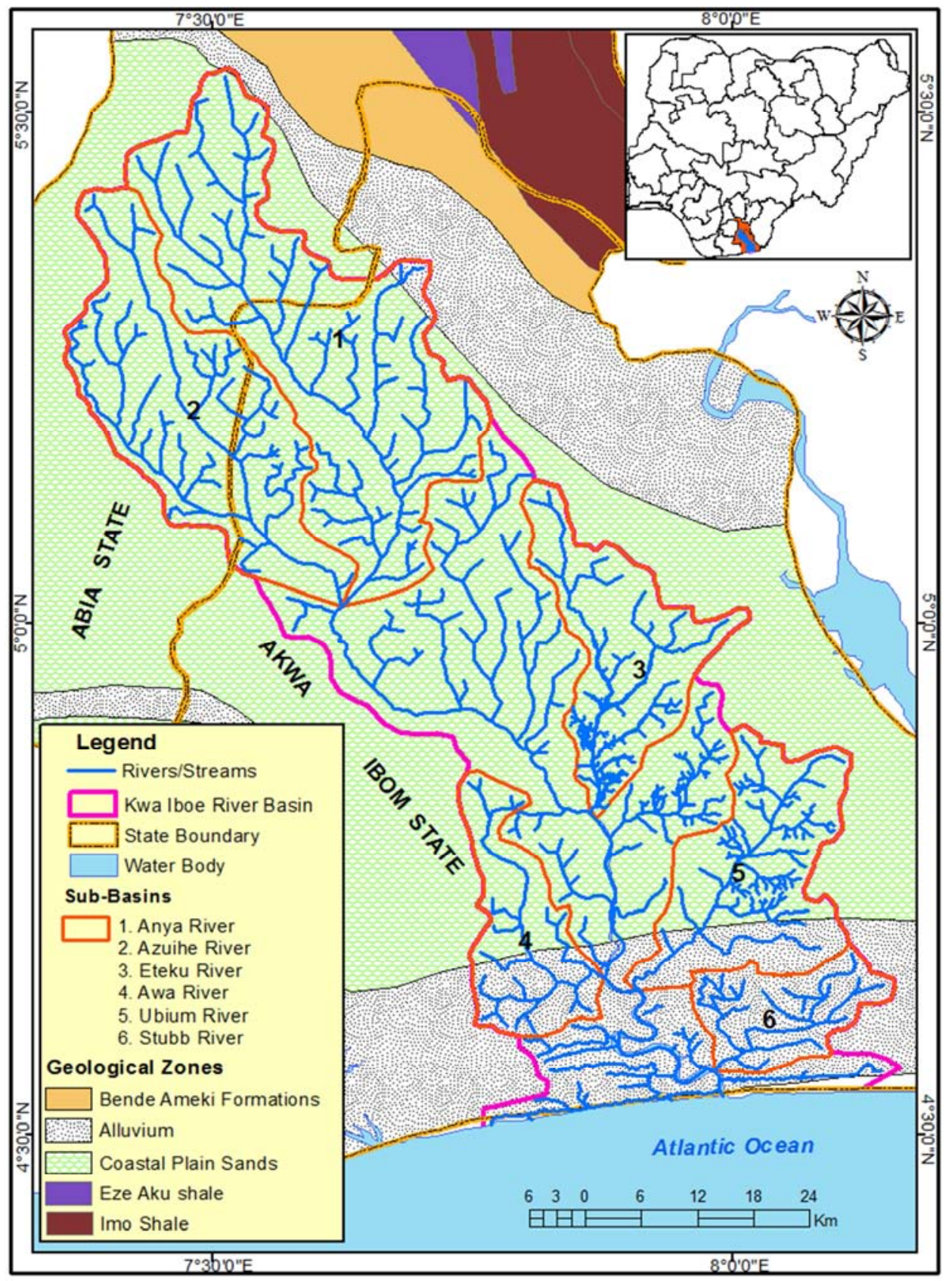

Source: Adapted from Umo (2019).

Figure 1. Kwa Iboe River Basin showing the Geological Formations.

The basin was stratified into six $4^{\text {th }}$ Order Rivers (comprising Anya, Azuihe, Awa, Eteku, Ubium, and Stubbs) 
sub-basins (Figure 1) for sub-basin area morphologic analyses based on Strahler [14] ordering scheme.

The maps were rectified and geo-referenced in GIS environment with Arc-GIS 10.2 software assigning Universal Transverse Mercator (UTM), World Geodetic System (WGS) dating from 1984 as revised in 2004). A 32N Zone Projection System with ERDAS Imagine 8.5 and Terrain Analysis System were employed as emphasized in $[1,4,8]$ to avert human errors. Data from distinct sources were analyzed both descriptively (using mean, media, mode, and standard deviation), and inferentially (using, one way analysis of variance, linear regression models and T-test). The analyses were performed using IBM computer aided software called statistical packages for social sciences (SPSS version 22.0) while a test of significance for null hypothesis was done at 0.95 confident level.

The linear regression is modelled as following:

$$
\mathrm{Y}=\mathrm{B}_{0}+\mathrm{B}_{1} \mathrm{X}_{1}+\mathrm{B}_{2} \mathrm{X}_{2}+\mathrm{B}_{3} \mathrm{X}_{3}+\ldots \mathrm{B}_{\mathrm{n}} \mathrm{X}_{\mathrm{n}}+\mathrm{E}
$$

\section{Data Analyses and Results}

Table 1. Descriptive Analyses of Spatio-temporal Distributions of Particulate Matters.

\begin{tabular}{|c|c|c|c|c|c|}
\hline Parameter & Sampled Unit & Mean (\%) & Median (\%) & Std. Deviation & $\mathbf{N}$ \\
\hline \multirow{9}{*}{$\begin{array}{l}\text { Sand } \\
0.05-2.0 \\
(\mathrm{~mm})\end{array}$} & 1 & 90.4 & 92.40 & 5.95 & 4 \\
\hline & 2 & 92.1 & 92.40 & 4.24 & 4 \\
\hline & 3 & 95.1 & 93.90 & 2.45 & 4 \\
\hline & 4 & 95.4 & 95.40 & 1.67 & 4 \\
\hline & 5 & 94.4 & 94.85 & 1.20 & 4 \\
\hline & 6 & 96.1 & 95.30 & 1.19 & 4 \\
\hline & 7 & 94.4 & 94.30 & 1.33 & 4 \\
\hline & 8 & 95.1 & 95.40 & 2.45 & 4 \\
\hline & Total & 94.1 & 94.80 & 3.22 & 32 \\
\hline \multirow{8}{*}{$\begin{array}{l}\text { Silt } \\
0.002-0.05 \\
(\mathrm{~mm})\end{array}$} & 1 & 1.8 & 1.75 & .79 & 4 \\
\hline & 2 & 3.6 & 1.90 & 3.62 & 4 \\
\hline & 3 & 2.1 & 1.40 & 2.13 & 4 \\
\hline & 4 & 2.4 & 2.05 & 1.50 & 4 \\
\hline & 5 & 2.5 & 2.45 & 1.20 & 4 \\
\hline & 7 & 2.1 & 1.90 & 1.77 & 4 \\
\hline & 8 & 2.8 & 2.70 & 2.02 & 4 \\
\hline & Total & 2.3 & 1.82 & 1.82 & 32 \\
\hline \multirow{9}{*}{$\begin{array}{l}\text { Clay } \\
<0.002(\mathrm{~mm})\end{array}$} & 1 & 7.8 & 6.40 & 5.47 & 4 \\
\hline & 2 & 4.2 & 4.20 & .92 & 4 \\
\hline & 3 & 2.8 & 3.00 & 1.01 & 4 \\
\hline & 4 & 2.1 & 2.20 & 1.12 & 4 \\
\hline & 5 & 3.2 & 3.00 & .25 & 4 \\
\hline & 6 & 2.5 & 2.90 & .77 & 4 \\
\hline & 7 & 2.5 & 2.20 & 1.73 & 4 \\
\hline & 8 & 3.2 & 2.90 & 1.98 & 4 \\
\hline & Total & 3.6 & 2.64 & 2.64 & 32 \\
\hline \multirow{7}{*}{ Organic_Matter } & 1 & .4 & .36 & .36 & 4 \\
\hline & 2 & .4 & .46 & .24 & 4 \\
\hline & 3 & .7 & .66 & .29 & 4 \\
\hline & 6 & .4 & .43 & .07 & 4 \\
\hline & 7 & 1.1 & .29 & 1.68 & 4 \\
\hline & 8 & .2 & .19 & .12 & 4 \\
\hline & Total & .5 & .62 & .62 & 32 \\
\hline \multirow{9}{*}{ Total Organic Carbon } & 1 & .2 & .28 & .23 & 4 \\
\hline & 2 & .4 & .37 & .13 & 4 \\
\hline & 3 & .4 & .15 & .15 & 4 \\
\hline & 4 & .5 & .46 & .30 & 4 \\
\hline & 5 & .3 & .31 & .10 & 4 \\
\hline & 6 & .3 & .33 & .08 & 4 \\
\hline & 7 & .3 & .31 & .10 & 4 \\
\hline & 8 & .3 & .33 & .08 & 4 \\
\hline & Total & .4 & .17 & .17 & 32 \\
\hline
\end{tabular}

$1=1^{\text {st }}$ Order, $2=$ Anya, $3=$ Azuihe, $4=$ Eteku, 5=Awa, $6=$ Ubium, $7=$ Stubbs, $8=$ Estuary. 
Table 2. Regression Model of Area Geomorphology and Particulate Matters Distributions.

\begin{tabular}{lllll}
\hline Model & R & R Square & Adjusted R Square & Standard Error of the Estimate \\
\hline 1 & $.954^{\mathrm{a}}$ & .909 & .456 & 190.028 \\
\hline
\end{tabular}

a. Predictors: (Constant), Organic Carbon, Clay, Silt, Organic Matter, Sand.

Table 3. ANOVA Model of the Influence of Area Morphology and Particulate Matters.

\begin{tabular}{llllll}
\hline Model & Sum of Squares & df & Mean Square & F & Sig. \\
\hline 1 Regression & 362030.380 & 1 & 72406.076 & 2.005 & $.488^{\mathrm{b}}$ \\
Residual & 36110.608 & 5 & 36110.608 & & \\
Total & 398140.989 & 6 & & & \\
\hline
\end{tabular}

a. Independent Variable: Area Morphology. b. Predictors: (Constant), Organic Carbon, Clay, Silt, Organic Matter, Sand.

Table 4. Regression and Correlation Models of Area Morphology on Particulate Matters.

\begin{tabular}{|c|c|c|c|c|c|c|c|}
\hline \multirow{2}{*}{\multicolumn{2}{|c|}{ Model }} & \multicolumn{2}{|c|}{ Unstandardized Coefficients } & \multirow{2}{*}{$\begin{array}{l}\text { Standardized Coefficients } \\
\text { Beta }\end{array}$} & \multirow{2}{*}{$\mathbf{T}$} & \multirow{2}{*}{ Sig. } & \multirow{2}{*}{$\begin{array}{l}\text { Zero-order } \\
\text { Coefficient }\end{array}$} \\
\hline & & B & Std. Error & & & & \\
\hline \multirow{6}{*}{1} & $(\text { Constant })^{\mathrm{a}}$ & -36756.35 & 2209.951 & & -1.66 & .346 & \\
\hline & Sand & 369.036 & 224.689 & 1.846 & 1.642 & .348 & -.624 \\
\hline & Silt & 377.007 & 178.245 & 1.139 & 2.115 & .281 & .723 \\
\hline & Clay & 285.731 & 197.746 & .947 & 1.445 & .385 & .601 \\
\hline & Organic_Matter & -400.062 & 515.107 & -.665 & -.777 & .580 & .278 \\
\hline & Organic_Carbon & 2161.66 & 1572.268 & 1.543 & 1.375 & .400 & .554 \\
\hline
\end{tabular}

a. Independent Variable: Area Morphology.

\section{Results and Discussions}

The characters of particulate matters are examined with a view to ascertaining the effect, association and variation of area morphology on particulate matters' distributions across seasons and locations in the Kwa Iboe River. The qualitative and quantitative results generated at the course of this study are chronological discussed in the sub-sections that follow.

\subsection{Spatio-temporal Distributions of Particulate Matters in the Kwa Iboe River}

The distributions of sand, silt, clay, total organic carbon sand, and organic matter across the various sampled units and climatic seasons is depicted in Table 1. The results of the distributions are based on descriptive statistics (mean, median, and standard deviation).

The data on sand distributions indicate that the highest value of 96.2 is recorded in the Ubium River, followed by 95.4 recorded in the Eteku River, and a value of 95.1 each is recorded in the Azuihe River and Estuary. The lowest mean value of 90.4 is recorded for the first-order stream. The grand average for sand parameter constitutes a value of 94.1 percent. This is contrary to [11] report of 76 percent of sand in Kano River project. The distribution of median class relates to the mean value with a highest value of 95.85 recorded in the Ubium River, followed by Azuihe River and Estuary each with a value of 95.40 . The lowest value of 92.40 is recorded in the $1^{\text {st }}$ order stream while the grand average associated with the median class is 94.80 (Table 1).

In order to determine the deviation of the sand particle distribution from the mean class, standard deviation was used. The results summarized in Table 1 indicate that the highest value of 5.948 is recorded in the $1^{\text {st }}$ Order stream, followed by 4.24 recorded in the Anya River, 2.45 in the Azuihe River. The lowest standard deviation of 1.19 is recorded in the Ubium River. The grand average standard deviation associated with the distribution of sand parameter is 3.22. A similar observation was made by [15] in Kuwait when suggesting that the high proportion of sand was due to the influence many factors (e.g. geology, climate, and discharge).

The values of silt indicate notable variability with respect to the mean, median and standard deviation of the distribution. At first, the mean distributions of silt range between a value of 1.325 for the lowest recorded at the Anya River and 3.675 for the highest value as recorded in the Ubium River. The grand mean associated with silt distribution gives a value of 2.334. Similarly, the median classes for silt converge between the lowest value of 1.40 recorded in the Azuihe River and the highest value of 2.70 recorded in the Estuary. The grand median is 1.82 . On the other hand, the standard deviation of the silt distribution recorded the lowest value of 0.51 in the Anya River and the highest value of 3.62 is recorded in the Awa River. The grand value for standard deviation gives 1.82.

The standard deviations in the distribution of clay vary across sub-basins and seasons in the Kwa Iboe River. The lowest value of 0.25 recorded in the Awa River, follows by 0.77 is recorded in the Ubium River and 0.92 recorded in the Anya River. Within the $1^{\text {st }}$ order stream, a highest standard deviation of 5.47 is recorded for clay. This is followed by 1.98 recorded in the Estuary and 1.73 recorded in the Stubbs River. Similarly, the grand average distributions of clay parameter yield 3.5 for mean, 2.64 for median and 2.64 for standard deviation.

The high proportion of clay distribution in the $1^{\text {st }}$ Order stream is attributed to the low discharge capacity, small channel, and protracted human activities via agriculture and urbanization.

On the other hand, the organic matter distributions across 
eco-geomorphologic units and in seasons vary with the lowest proportion of 0.2 is recorded in the Estuary and the highest value of 1.1 recorded in the Stubbs River. The grand mean distribution yields a value 0.5 . The median class of the distribution of the organic matter range between the values of 0.19 recorded in the Estuary and 0.73 in the Eteku River. The grand median class reveals a proportion of 0.62 . The standard deviation of the organic matter distribution yields a highest value of 1.68 in the Stubbs River and a lowest value of 0.07 in the Ubium River.

The mean, median, and standard of distribution of organic carbon across eco-geomorphologic units and in seasons vary (Table 1). The lowest mean proportion of 0.2 is recorded in the $1^{\text {st }}$ order stream and the highest value of 0.5 is recorded in the Eteku River. Also, the median distribution of organic carbon depicts that highest value of 0.46 in the Eteku River and the lowest value of 0.15 in the Azuihe River. The grand median of the distribution gives a value 0.17 .

In consideration of the research question one, the distributions of particulate matters show a dominance of sand with a value of 94.1 percent. This is followed by clay controlling $3.6 \%$ of the particulate matters, and silt controlling $2.3 \%$ of the particulate matters in the river. The results are distinct from [11] report of $76 \%$ sand, $12 \%$ silt, and $12 \%$ clay in Kano River Canal. The discrepancies in the findings can be ascribed to differences in local geomorphological factors (such as discharge characteristics, geology, rainfall, and location, topography) accelerated by anthropogenic parasitism (such as mining, engineering works, and land use practices) within the study area. Similar studies with fairly similar reports have been envisioned outside the basin by $[3,16]$.

\subsection{Influence of Morphology on Particulate Matters' Distributions}

The data on particulate matters across distinct sampled locations and in seasons were analyzed in the laboratory were statistically modelled. The influence of the area morphology (independent variable) on the distribution of sand, silt, clay, organic matter, and organic carbon (dependent variables) was evaluated using a multiple linear regression model and the result is presented in Table 2. The result of the model reveals that the coefficient of multiple determination $(\mathrm{R})$ is 0.954 which suggests a very high positive influence of the variation in area morphology on the spatial distribution of the five particulate matters across eco-geomorphologic units in KIRB. The R square of 0.909 implies that 90.9 percent of the proportion of variations in the distribution of sand, silt, clay, organic matter, and organic carbon is influenced by a change in area morphology. The remaining value of 9.1 percent is associated with other factors which may be agricultural practices, mining activities, geology, and vegetation. The standard error of estimate connected with the model is 190.028 .

In order to test for significance of the combined influence of area morphology on the mean distribution of sand, silt, clay, organic matter, and organic carbon across the eco-geomorphologic units, ANOVA is used. The results presented in Table 3 showed that the computed F-value is 2.005 and the Table value tested at $(0.05)_{1 / 5}$ confidence level gives 6.608. Since the calculated $F$ value is less than the Table value, the null hypothesis one is accepted. That is, variations in area morphology have no significant influence on the particulate matters' distributions in the Kwa Iboe River basin. Though differences exist in the numbers of measurable morphological and sediment parameters, the finding corroborated [17] observation in the Peruvian coastal River basin that no significant relationships were found between the coast morphology and the grain size distributions across sampled area.

However, though the multiple regression model demonstrated a high positive coefficient of 0.954 and a high proportion (90.9\%) of explainable variance, ANOVA test reveals that the dominant factors that influence the distribution the five particulate matters fall outside area morphology. Such factors may include surface runoff, erosion, location, discharge characteristics, mining, vegetation, or agricultural practices that are operational in the Kwa Iboe River. Accordingly, the result supported [18, 19] notions that the fully dispersed particulate distributions are usually influenced by many factors notably fluvial processes and forms that are operational within a River Basin.

\subsection{Associations and Variations in Area Morphology and Particulate Matter Distribution}

A partial regression coefficient is used to assess the association between the independent variable (area geomorphology) and each dependent variable (particulate matters) in KIRB and the results are presented in Table 4. The results of the unstandardized coefficients B gave -36756.35 for constant value; 369.036 for sand; 377.007 for silt; 285.731 for clay; -400.06 for organic matter and 2161.66 for organic matter. The standardized beta coefficients yielded 1.846 for sand, 1.139 for silt, 0.947 for clay, -0.665 for organic matter, and 1.543 for organic carbon. The highest positive relationship is depicted by sand, followed by organic carbon, silt and clay; while organic matter showed a negative association.

In consideration of the standardized beta coefficients, the association of the area morphology on each of the five dependent parameters is modelled in the equation thus:

$$
\mathrm{Y}=-36756.35+1.846 \mathrm{x}_{1}+1.139 \mathrm{x}_{2}+0.947 \mathrm{x}_{3}-0.665 \mathrm{x}_{4}+1.543 \mathrm{x}_{5}+\mathrm{e}(190.028)
$$

Where $\mathrm{x}_{1}$ is sand, $\mathrm{x}_{2}$ is silt, $\mathrm{x}_{3}$ is clay, $\mathrm{x}_{4}$ is organic matter, and $x_{5}$ is organic carbon while $e$ is the standard error of the estimate.

Inferring from the result of the partial regression model presented as equation 2, only organic matter with a negative association showed a converging role with area morphology. On the contrary, sand, silt, clay, and organic carbon each exhibits a diverging pattern of association with area 
morphology. The implication is that a negative change in the area morphology attracted a proportionate negative change in the distribution of organic matter. Besides, a positive change in area morphology attracts a proportional positive change each in the distribution sand, silt, clay, and organic carbon.

In order to determine the strength of the relationships between area morphology and each particulate parameter, a zero-order correlation is used and the results are summarized in Table 4. The zero-order correlation gave a high positive coefficient between area morphology and silt (0.723), clay (0.601), organic carbon $(0.554)$, while sand $(-0.624)$ reveals a high negative coefficient and each is significant at 0.05 confidence level. However, silt exercised a higher degree of influence in the relationship. This is followed by sand, clay, and then organic carbon. However, the organic matter exhibits a very low positive coefficient of 0.278 and is not significant at 0.05 confidence level. The positive correlation coefficients suggest that a rise in a given unit of the independent variable while holding other variables constant will attracts a corresponding increase in the unit of each dependent variable and vice versa. Also, the negative coefficient is an indication that a decline in the size of area morphology by certain unit attracts a corresponding decline on the distribution of sand fraction in KIRB.

In furtherance of the attempt to establish whether the mean distribution of each particulate matter significantly differs with area morphology in the Kwa Iboe River, the student's t-test is used. The results summarized in Table 4 showed that the area morphology exhibits a direct negative effect on mean organic matter distribution with a t-test value of -0.777 . The remaining four parameters each indicate an inverse (positive) value on the independent variable. Accordingly, the sand particles distribution gave a positive t-test value of 1.642 , silt particles distribution gave a value of 2.115 , clay particle 1.445 and organic matter 1.375. However, the results of t-test values were not significant at 0.05 confidence level.

\subsection{Implications of Findings on Kwa Iboe River Basin Restoration}

The discourse of findings on the preceding section implies that variation in the area morphology exhibits a diverging influence on the mean sand, silt, clay, and organic carbon distributions; while the mean organic matter content reveals a converging influence in the study area, such influence were not statistically significant. The implication of the result is that the entire catchment is under the influence of two (unidirectional and bi-directional) flows that instigate turbulent fluvial hazards, weathering and mass wasting processes.

The upper and middle catchments exhibited a uni-directionality in the operations of the fluviogeomorphological processes leading to river bed and channel modifications, water quality contamination and silting of first-order tributaries by natural and anthropogenic agents. The lower catchment especially areas closed to the Atlantic Oceanic is exhibiting bi-directionality in the operations of fluvial processes due to the influence of Ocean tide, waves and ebb flow. Therefore, restoration of the silted first order tributaries at the upper sub-catchment in the Kwa Iboe River demand the used of legislative and engineering measures.

From the legislative perspective, the Federal, State and Local Government Agencies should partner the watershed communities to build formidable blocs that will facilitate the stringent enforcement of existing water and river protection Laws within the riverine areas. Such organized efforts will aid in the protection of the river water, mitigate the rate of siltation accelerated by sediment yield from surface runoff, and waste dumped either directly into the water bodies or at the drainage systems, but transported into the Rivers channels from the highly urbanized axes of Umuohia and Ikwano.

This study also established that variations in area morphology do not have significant influence on the mean distribution of particulate matter distributions. The implication of the finding is that siltation, abstraction, and allied process-induced hazards that are prevalence at the upper and middle sub-catchments of the Kwa Iboe River could be better explained by other factors such as urbanization, mining, climate, discharge and agricultural practices that were not accounted for in this study. Therefore, protecting and restoring the first order tributaries from further siltation and/ or abstraction require proactive engineering measures such as dredging of the channels to remove blockages, construction drainages to regulate surface runoff from the urbanized Umuohia area (the Abia State Capital) to the River system, and total ban of mining activities in the catchment.

Similarly, the dominancy of sand particulate matters suggests increased in sediment yield from diverse gully complexes especially within the rural communities and towns Obot Akara, Nsit clan, Essien Udim, Ikwano, and Umuohia as accelerated by high incidences of elevation, rainfall, runoff, discharge and anthropogenic interferences. The identified scenarios suggest urgent need for appropriate catchment management plan that will accommodate the state of the art upstream erosion and downstream flood controls and the resultant devastating impacts on the people lives, properties and environment within the eco-geomorphologic units (sub-catchment areas) in recent times.

\section{Conclusion}

From the preceding discourses, it is established that the distributions of particulate matters are dominated by sand fractions, followed by clay, and silt. The result suggested strong influence of the amalgams of geomorphological and geographical variables such as pedology, discharge, climate, and relief of KIRB. The incidences of sediment and waste mantle accumulation at the upper and middle sub-basins directly relate high topography, geology and soil classes which increase the area vulnerability to varying degrees of geomorphic hazards such as gully/rill erosion, channel migration, silting and drying up of first-order streams especially at the upstream and middle stream areas as accelerated by high rate of infiltration capacity associated with dominant sand particles. 
Similarly, the statistical tests clearly indicated that basin morphology induced no significant control of particulate matters distribution in the Kwa Iboe River Basin. That means the incidences of coastal erosion and marine/ coastal flood that are peculiar to the downstream and estuarine areas of the Kwa Iboe River Basin can be attributed to the role of discharge characteristics, geology, proximity to Atlantic Ocean, vegetation, and poorly regulated human exploitative excesses (anthropogenic parasitism). There is urgent need for the implementation of proactive people-oriented river restoration measures that can assuage or avert the hazards confronting the sustainability and use of the Kwa Iboe River Basin for socio-economic and agricultural development of Southeastern Nigeria in this $21^{\text {st }}$ century.

\section{Declaration}

The authors' declare that there is no conflicting interest in this article.

\section{Acknowledgements}

We gratefully acknowledged the supports and efforts of Dr. Umo I. Sunday family, Deaconess Agnes Sunday Umo and TETFund Nigeria, 2016/2017 intervention for staff development allocated to Alvan Ikoku Federal College of Education, Owerri, and staff and managements of the Alvan Ikoku Federal College of Education Owerri and that of University of Benin, Nigeria for their diverse supports.

\section{References}

[1] Hajam R. A., Hamid A., and Bhat S. Application of morphometric analysis for geo-hydrological studies using geo-spatial technology -a case study of Vishav drainage basin. Hydrological Current Research, 4, 2013, 157. Available online on http://dx.doi/10.4172/2157-7587.1000157

[2] Ezemonye Mary N., Umo Ikpong Sunday, Ike, Ojinma Chux Chukwuma and Enwereuzor, Angela Iweka. Geomorphometric parameters of Ikpa River and its implications for the planning of fluvial hazards in the Northeast of Akwa Ibom State. Journal of Geography, Environment and Earth Science International, 11 (1), 2017, 1-12. Accessed online on 17/1/2018 from http://dx.doi.org/10.9734/JGEESI/2017/34674

[3] Umo Ikpong Sunday, Ezemonye Mary N., Ike, Mbaeri Chris, and Ojinma Chux Chukwuma. Dimensional basin morphometry and discharge in the Coastal Plains Sands of Ikpa River, Akwa Ibom State, Nigeria. Journal of Geography, Environment and Earth Science International, 13 (3), 2018, 1-13. Available http://dx.doi.org/10.9734/JGEESI/2017/38699

[4] Farhan Y., Elmaji I. and Khalil O. GIS-Based morphometric analysis of fourth- order sub-basins of the Zerqa River (Jordan) using multivariate statistical techniques. Natural Resources, 7, 2016, 461-480. http://dx.doi.org/10.4236/nr.2016.78040

[5] Jesuleye I. A., Okeke U. H., Atijosan A. O., Badru R. A.,
Adewoyin J. E. and Alaga A. Morphometry assessment of Oba River Basin and its implications for flood. Journal of Geography, Environment and Earth Science International, 8 (3), 2016, 1-10.

[6] Meitzen K. M., Doyle M.W., Thoms M. C. and Burns C. E. Geomorphology within the interdisciplinary science of environmental flows. Geomorphology, 200, 2013, 143-154.

[7] National Research Council. New research opportunities in the earth sciences at the National Science Foundation. Washington DC, National Academies Press, 2012.

[8] Umo I.S. The dynamics of sediments, heavy metals, and nutrients in the Kwa Iboe River, Southeastern Nigeria. Ph.D thesis, University of Benin, 2019, 229 pages.

[9] Brierley G., Fryirs K. and Jain V. Landscape connectivity: The geographic basis of geomorphic applications. Area, 38 (2), 2006, 165-174.

[10] Zavoianu I. Relationships between suspended sediment load discharge and the total number and length of stream segments. Journal of Geography and Regional Planning, 6 (2), 2013, 31-40. Retrieved from http://dx.doi.org/10.5897/JGRP11.123

[11] Tukur A. I., Olofin E. A., Mashi, S. A. Rate of sediment yield in the conveyance canals of Kano River Irrigation Project (Phase I) North-Western Nigeria. Journal of Environment and Earth Science, 3 (12), 2013, 155-162.

[12] Ofomata G. E. K. (1985). Nigeria in maps: Eastern States. Benin, Ethiope Publishing House.

[13] Usoro E. J., Akpan P. A. (Editors). Akwa Ibom State: A geographical perspective. Enugu, Immaculate Publication Limited 2010.

[14] Strahler A. Dynamic basis of geomorphology. Geological Societal of America Bulletin, 63, 1952, 923-938.

[15] Elhabab A. A. A., Adsani I. Geochemical and mineralogical characters of the coastal plain sediments of the Arabian Gulf, Kuwait. Journal Geology and Geosciences, 3, 2013, 137 - 148. http://dx.doi.org/10.4172/2329-6755.100013

[16] Surian N. Downstream variation in grain size along an Alpine River: Analysis of controls and process. Geomorphology, 43, 2002, 137-149.

[17] Litty C., Schlunegger F., Viveen W. Multiple controls on sediment grain properties of Peruvian Coastal River Basins. Discussion paper on Earth Surface Dynamics. Retrieved on April 17, 2017 from http://dx.doi.org/10.5194/esurf-2017-8

[18] Di Stefano C., Ferro V. Linking clay enrichment and sediment delivery processes. Bio-system Engineering, 81 (4), 2002, 465-477.

[19] Mohtar W. H. M. W., Bassa S. A., Porhemmat M. Grain size analysis of surface fluvial sediments in Rivers in Kelantan, Malaysia. Sains Malaysiana, 46 (5), 2017, 685-693. http://dx.doi.org/10.17576/jsm-2017-4605-02

[20] Ituen U. J. and Johnson I. U. Kwa Iboe River: Its physical characteristics and economic potentials to host communities in Abia and Akwa Ibom States, Nigeria. The International Journal of Social Sciences and Humanities Invention. 2 (1), 2015, 922-934. 